\title{
Analisis Sumber dan Penggunaan Modal Kerja Pada Dodol Kentang Putri Pancuran Tujuh Lubuk Nagodang Kerinci Periode 2017 - 2019
}

\author{
Enny Sestriyenti \\ AMIK Depati Parbo Kerinci \\ ennysestriyenti180@gmail.com
}

\author{
Fatma Ariani \\ Universitas Putra Indonesia YPTK Padang \\ fatmariani6@upiyptk.ac.id
}

\section{Nike Apriyanti}

Universitas Putra Indonesia YPTK Padang

nike_apriyanti@upiyptk.ac.id

\section{Mutia Seplinda}

Universitas Putra Indonesia YPTK Padang

mutia.seplinda@upiyptk.ac.id

\begin{abstract}
Abstrak Modal kerja merupakan unsur yang sangat penting bagi perusahaan karena tanpa modal kerja yang cukup, aktivitas operasional suatu perusahaan tidak dapat dilangsungkan. Untuk dapat menjaga kelangsungan hidup perusahaan dan untuk mampu bersaing dengan perusahaan yang lainnya, perusahaan harus dapat mengelola seluruh kekayaan, kewajiban, dan modal yang dimiliki semaksimal mungkin. Analisis sumber dan penggunaan modal kerja dan rasio likuiditas (current ratio) sering digunakan sebagai indikator untuk menilai efektivitas dan efisiensi modal kerja suatu perusahaan, dan mengukur kemampuannya dalam melunasi seluruh kewajiban jangka pendeknya. Usaha Dodol Kentang Putri Pancuran Tujuh Lubuk Nagodang Kerinci yang bergerak pada pengolahan dodol Kentang. Dari hasil penelitian dan pembahasan, dilihat bahwa perkembangan modal kerja bersih yang dimiliki oleh Dodol Kentang Putri Pancuran Tujuh Lubuk Nagodang Kerinci pada tahun 2017-2019 adalah berfluktuasi.
\end{abstract}

Kata Kunci Sumber, Penggunaan Dana, Modal Kerja

\section{PENDAHULUAN}

Pendirian perusahaan pada umumnya bertujuan untuk memaksimalkan keuntungan dan nilai perusahaan sehingga perusahaan dapat mempertahankan kelangsungan usahanya, mengembangkan usahanya dan memperoleh laba maksimum sehingga tujuan memaksimumkan nilai perusahaan pada akhirnya dapat tercapai. Dalam usaha pencapaian tersebut diperlukan suatu manajemen yang baik, sehingga perusahaan dapat dikelola secara efektif dan efisien melalui perencanaan, pengorganisasian, pengarahan serta pengawasan yang menyangkut fungsi-fungsi dari aspek manajerial maupun aspek operasional perusahaan seperti fungsi pemasaran, fungsi produksi, fungsi personalia dan fungsi keuangan. Setiap fungsi tersebut saling berhubungan dan saling mempengaruhi. 
Salah satu fungsi operasional yang mendukung dalam suksesnya suatu perusahaan adalah fungsi keuangan yang disebut dengan manajemen keuangan. Ada tiga keputusan utama dalam manjemen keuangan suatu perusahaan yaitu, keputusan pembelanjaan atau pembiayaan, keputusan investasi dan kebijakan deviden. Khusus untuk keputusan pembiayaan yaitu keputusan dari mana sumber dana diperoleh dengan biaya yang minimal dan untuk apa dana tersebut digunakan agar memperoleh keuntungan yang maksimal.

Dana dapat berasal dari intern perusahaan yaitu dana yang dihasilkan sendiri di dalam perusahaan yang berupa laba ditahan dan penyusutan. Sedangkan dana ekstern perusahaan yaitu berasal dari kreditur yang berupa (hutang atau pinjaman), baik dalam jangka panjang maupun jangka pendek. Menurut Adelina \& Darman (2021) bahwa masalah keuangan merupakan masalah penting dalam perusahaan karena dana yang masuk ke dalam perusahaan merupakan modal bagi perusahaan untuk melakukan kegiatan sehari-hari. Pada dasarnya modal aktif dapat dibedakan menjadi : Modal Kerja dan Modal Tetap. Modal kerja adalah dana yang diperlukan untuk membelanjai kegiatan perusahaan sehari-hari, sedangkan modal tetap adalah modal yang ditanamkan ke dalam aktiva perusahaan. Modal kerja dibutuhkan untuk membiayai kegiatan pokok perusahaan, dibanding dengan modal tetap, maka modal kerja sifatnya lebih fleksibel, jumlah modal kerja lebih mudah diperbesar atau diperkecil sesuai dengan kebutuhan dan elemenelemen modal kerja mudah berubah-ubah. Unsur modal kerja pada umunya terdiri dari : kas, surat-surat berharga, piutang, persediaan, dan uang muka dan seluruh unsur-unsur yang ada dalam modal kerja perlu dikelola dengan baik.

Manajemen modal kerja berhubungan dengan keputusan investasi pada aktiva lancar dan hutang lancar terutama mengenai bagaimana menggunakan dan komposisi keduanya akan mempengaruhi resiko. Modal kerja diperlukan perusahaan untuk membiayai kegiatan operasional perusahaan. Ada dua pengertian modal kerja, yang pertama Gross Working Capital, adalah keseluruhan komponen-komponen aktiva lancar, yang kedua Net Working Capital adalah kelebihan aktiva lancar diatas hutang lancar. Manajemen modal kerja yang efektif mejadi sangat penting untuk pertumbuhan kelangsungan perusahaan dalam jangka panjang. Aktiva lancar itu sendiri terdiri dari aktiva lancar permanen dan aktiva lancar variabel.

Untuk mengelola dan mengatur keuangan perusahaan, manajer keuangan seringkali dihadapkan pada berbagai masalah yang rumit, salah satu penyebabnya adalah kurang tepatnya kebijaksanaan keuangan yang ditempuh oleh perusahaan dan terdapat adanya ketidakseimbangan antara sumber dana yang tersedia dengan jumlah penggunaan dana yang akan terjadi. Bila jumlah dana yang tersedia lebih kecil dari jumlah dana yang dibutuhkan maka akan terganggunya kegiatan perusahaan. Begitu pula sebaliknya apabila jumlah dana yang tersedia lebih besar dari jumlah dana yang dibutuhkan maka adanya dana yang tidak produktif atau banyak dana yang tidak dimanfaatkan sehingga perusahaan kehilangan kesempatan untuk memperoleh keuntungan, bahkan lebih jauh lagi akan membawa kerugian. Oleh karena itu, modal kerja yang tersedia hedaknya sesuai dengan kebutuhannya dan dalam usaha pemenuhan (sumber) dan penggunaan dana tersebut haruslah mempertimbangkan keseimbangan keuangan agara tercapai tujuan perusahaan.

Dengan demikian besar kecilnya modal kerja merupakan fungsi dari berbagai faktor seperti :

1. Jenis produk yang dibuat

2. Jangka waktu siklus operasi 
3. Tingkat penjualan, semakin tinggi tingkat penjualan maka kebutuhan investasi pada persediaan juga akan semakin besar

4. Kebijakan persediaan

5. Kebijakan penjualan kredit

6. Seberapa jauh efisiensi manajemen aktiva lancar.

Desa Lubuk Nagodang merupakan desa penghasil produk dodol kentang dikabupaten Kerinci Provinsi Jambi. Usaha Dodol Putri Pancuran Tujuh memproduksi dodol rata-rata 15.000 buah perhari. Letak Usaha Dodol Putri Pancuran Tujuh sekitar $\pm 20 \mathrm{~km}$ dari kota Sungai Penuh. Perusahaan ini juga tidak bisa terlepas dari masalah pengolahan pembelanjaan yang meliputi sumber-sumber dan penggunaan modal kerja yang tepat agar kelangsungan hidup perusahaan tidak terganggu.

Dari data laporan keuangan Usaha Dodol Putri Pancuran Tujuh selama tiga periode (2017 - 2019) dapat diketahui perkembangan aktiva lancar dan hutang lancar sebagai berikut bahwa perkembangan aktiva lancar pada tahun 2017-2019 berfluktuasi. Dimana pada tahun 2017 aktiva lancar meningkat sebesar 35,34\%, namun mengalami penurunan sebesar 40,53\% di tahun 2018. Perkembangan Hutang Lancar dapat diketahui bahwa perkembangan hutang lancar pada periode 2017-2019 juga berfluktuasi. Pada tahun 2017, hutang lancar meningkat sebesar 27,85 \% namun mengalami penurunan sebesar $13,63 \%$ ditahun 2018.

Dari uraian diatas diketahui bahwa nilai aktiva lancar lebih besar dari nilai hutang lancar. Menurut Ridwan S. Sundjaja dan Inge Barlian (2002) jika aktiva lancar melebihi hutang lancar, perusahaan mempunyai modal kerja bersih positif. Hal ini mengindikasikan bahwa kebijaksanaan pembiayaan modal kerja sesuai dengan prinsip pembiayaan yaitu semua yang diperoleh dari sumber dana jangka pendek harus digunakan untuk menutupi kebutuhan yang bersifat jangka pendek pula. Namun bisa juga mengindikasikan adanya dana yang tidak produktif. Menurut S. Munawir (2007) modal kerja yang berlebihan menunjukkan adanya dana yang tidak produktif, hal tersebut akan menimbulkan kerugian bagi perusahaan karena adanya dana yang tidak produktif, hal tersebut akan menimbulkan kerugian bagi perusahaan karena adanya kesempatan untuk memperoleh keuntungan telah disia-siakan dan sebaliknya jika kekurangan modal kerja maka akan mengganggu likuiditas perusahaan.

\section{LANDASAN TEORI}

\section{Modal Kerja}

Menurut Yanti, Sujana, \& Zukhri (2019) modal kerja bruto adalah keseluruhan aktiva lancar. Sedangkan modal kerja bersih adalah aktiva lancar dikurangi dengan kewajiban lancar atau investasi perusahaan dalam bentuk uang tunai, surat berharga, piutang danpersediaan dikurangi kewajiban lancar yang digunakan untuk membiayai aktiva lancar, (kelebihan aktiva lancar diatas hutang lancar). Sedangkan menurut Adelina \& Darman (2021) modal kerja adalah jumlah keseluruhan aktiva lancar atas hutang lancar. Pada dasarnya modal kerja adalah dana dari jumlah keseluruhan aktiva lancar dan atau kelebihan aktiva lancar atas hutang lancar.

\section{Laporan Sumber dan Penggunaan Modal Kerja}

Menurut Yanti et al., (2019) laporan sumber dan penggunaan modal kerja adalah suatu laporan yang menggambarkan dari mana datangnya dan untuk apa dana itu digunakan. Sedangkan menurut Munawir (2007) laporan sumber dan penggunaan modal kerja adalah 
menggambarkan suatu ringkasan sumber dan penggunaan dana selama periode yang bersangkutan.

\section{Analisis Sumber dan Penggunaan Dana Dalam Artian Kas}

Menurut Munawir (2007) Analisis Sumber dan Penggunaan Kas (cash flow statement analiysis) adalah suatu analisis untuk mengetahui sebab-sebab berubahnya jumlah uang kas atau mengetahui sumber-sumber serta penggunaan uang kas selama periode tertentu. Sedangkan menurut Sutrisno (2007) analisis sumber dan penggunaan kas adalah suatu analisis untuk mengetahui sumber-sumber dan penggunaan kas untuk mengetahui penambahan dana atau pengurangan dana akan menambah atau mengurangi kas.

\section{Analisis Sumber dan Penggunaan Dana Dalam Artian Modal Kerja}

Menurut Bambang Riyanto (2001) Analisis Sumber dan Penggunaan Modal Kerja adalah suatu analisa untuk mengetahui bagaimana kebutuhan dana tersebut dibiayai atau dengan kata lain dari mana datangnya dan untuk apa dana digunakan. Sedangkan menurut Sutrisno (2007) analisis sumber dan penggunaan modal kerja adalah suatu analisis untuk mengetahui sumber - sumber dan penggunaan modal kerja utnuk mengetahui penambahan dana akan menambah modal kerja, dan penggunaan dana diaggap akan mengurangi modal kerja. Sehingga laporan ini memberikan gambaran tentang bagimana manajemen mengolah perputaran atau sirkulasi modalnya,

\section{Analisis Kebijakan Sumber dan Penggunaan Dana}

Menurut Bambang Riyanto (2001) Analisis Kebijakan Sumber dan Penggunan Dana dimaksudkan untuk menilai kebijakan perusahaan yang bersangkutan dalam penggunaan dana dan cara mendapatkannya.

Analisis modal kerja sangat penting mengingat kegiatan usaha perusahaan di dalam operasi sehari-harinya. Pengendalian jumlah modal kerja yang tepat akan mejamin kontinuitas operasi dari perusahaan secara efisien dan ekonomis. Bilamana modal kerja terlalau besar, maka dana yang tertanam dalam modal kerja melebihi kebutuhan. Padahal dana itu sendiri sebenarnya dapat digunakan untuk keperluan lain dalam rangka peningkatan laba. Tetapi bilamana modal kerja terlalu kecil, maka perusahaan akan kurang mampu memenuhi permintaan langganan seperti pembelian bahan mentah, membayar gaji pegawai dan upah buruh atupun kewajiban-kewajiban lainnya yang segera harus dilunasi.

Menurut Bambang Riyanto (2001) modal kerja memiliki tiga konsep yang biasa digunakan untuk analisis yaitu :

\section{Modal Kerja Kuantitatif}

Konsep ini menitikberatkan pada segi kuantitas dana yang tertanam dalam aktiva yang masa perputarannya kurang satu tahun. Modal kerja menurut konsep ini adalah keseluruhan elemen aktiva lancar. Oleh karena semua elemen aktiva lancar diperhitungkan sebagai modal kerja tanpa memperhatikan kewajiban-kewajiban jangka pendeknya, maka modal kerja ini sering disebut modal kerja bruto atau Gross Working Capital.

2. Modal Kerja Kualitatif

Pada konsep ini, modal kerja bukan semua aktiva lancar tetapi telah mempertimbangkan kewajiban-kewajiban yang segera harus dibayar. Dengan demikian dana yang digunakan benar-benar khusus untuk membiayai operasi perusahaan sehari-hari tanpa khawatir terganggu oleh pembayaran-pembayaran hutang yang segera jatuh tempo. Karena 
menurut konsep ini hutang lancar telah dikeluarkan dari perhitungan, sehingga modal kerja merupakan selisih aktiva lancar dengan hutang lancarnya.

3. Modal Kerja Fungsional

Pengertian modal kerja menurut konsep ini adalah dana yang digunakan oleh perusahaan untuk menghasilkan current income sesuai dengan tujuan didirikannya

perusahaan pada suatu periode tertentu. Oleh karena itu yang masuk sebagai modal kerja adalah kas, piutang dagang, persediaan, dan aktiva tetap.

\section{METODOLOGI PENELITIAN}

\section{Metode Analisis}

1. Deskriptif kuantitatif

Adalah metode yang digunakan untuk menganalisa terhadap data yang ada di dalam perusahaan dengan cara membandingkan teori atau konsep mengenai prinsip pembiayaan modal kerja serta sumber dan penggunaan modal kerja dan seberapa besar mempengaruhi kemampuan menghasilkan laba terhadap perusahaan.

2. Deskriptif Kualitatif

Adalah metode yang digunakan dengan cara membandingkan neraca dan laporan rugi laba dari tahun ke tahun serta menghitung perubahan yang terjadi lalu menghitung laba yang dihasilkan.

\section{Alat Analisis}

\section{a. Alat analisis yang digunakan adalah:}

1. Modal kerja bersih yaitu selisih antara current asset (aktiva lancar) dengan current liabilities (hutang lancar). Dapat diformulasikan sebagai berikut :

$$
\begin{aligned}
& \text { Modal Kerja Bersih = Total Aktiva Lancar }- \text { Total Hutang } \\
& \text { Lancar }
\end{aligned}
$$

2. Alat Analisis Trend Horizotal

Untuk mengetahui perkembangan aktiva lancar dengan membandingkan masing -masing komponen dalam aktiva lancar antara tahun tertentu dengan tahun sebelumnya baik dalam rupiah maupun dalam persentase.

Rumus yang digunakan adalah sebagai berikut :

$$
\frac{\mathrm{Ta}-\mathrm{Td}}{\mathrm{Td}} \times 100 \%
$$

Dimana : $\mathrm{Ta}=$ tahun yang dianalisa $\mathrm{Td}=$ tahun dasar

3. Analisa Perubahan Modal Kerja

Suatu metode untuk mengetahui sebab-sebab terjadinya perubahan modal kerja selam periode yang bersangkutan. Hasil dari analisis ini adalah laporan perubahan modal kerja yang menggambarkan perubahan dari masing-masing unsur modal kerja atau unsur Current Account antara dua titik waktu. Dari laporan tersebut diketahui adanya kenaikan atau penurunan modal kerja beserta beasrnya perubahan modal kerja.

4. Analisis Sumber dan Penggunaan Modal Kerja

Bambang Riyanto (2001) menyebutkan bagaimana proses penyusunan laporan sumber dan penggunaan modal kerja adalah sebagai berikut :

a. Menyusun laporan perubahan modal kerja mengelompokkan perubahan dari unsur non current account antara dua titik waktu tersebut ke dalam golongan yang memperbesar atau memperkecil modal kerja.

b. Mengelompokkan unsur-unsur ke dalam laporan laba ditahan ke dalam golongan yang memperbesar atau memperkecil modal kerja.

c. Berdasarkan informasi tersebut diatas dapatlah disusun laporan sumber dan penggunaan modal kerja, 


\section{HASIL PENELITIAN}

\section{Perkembangan Modal Kerja Bersih Dodol Kentang Putri Pancuran Tujuh Lubuk Nagodang Kerinci}

Setiap perusahaan selalu membutuhkan modal kerja untuk membelanjai kegiatan opersional sehari-hari, dimana yang telah dikeluarkan diharapkan akan dapat kembali lagi masuk dalam perusahaan dalam waktu yang pendek melalui hasil penjualan produksinya. Dengan demikian maka dana akan terus-menerus berputar setiap periodenya selama hidupnya perusahaan (Bambang Riyanto, 2001). Modal kerja sebaiknya tersedia dalam jumlah ynag cukup agar memungkinkan perusahaan untuk beroperasi secara ekonomis dan tidak mengalami kesulitan keuangan.

Untuk mengetahui perkembangan modal kerja bersih Dodol Kentang Putri Pancuran Tujuh Lubuk Nagodang Kerinci periode 2017-2019 digunakan alat analisis trend horizontal yaitu dengan membandingkan masing-masing komponen dalam neraca (Aktiva lancar dan Hutang lancar), karena modal kerja bersih didapat dari selisih antara aktiva lancar dengan hutang lancar maka relebih dahulu dijelaskan perkembangan unsurunsur aktiva lancar dan hutang lancar. Perkembangan modal kerja bersih Dodol Kentang Putri Pancuran Tujuh Lubuk Nagodang Kerinci periode 2017-2019 dapat dilihat pada tabel berikut :

Tabel 1. Laporan Perkembangan Modal Kerja Bersih Dodol Kentang Putri Pancuran Tujuh Lubuk Nagodang Periode 31 Desember 2017 - 31Desember 2019 ( Ribuan Rupiah )

\begin{tabular}{|l|r|r|r|}
\hline \multicolumn{1}{|c|}{ Keterangan } & 2017 & 2018 & 2019 \\
\hline AKTIVA LANCAR & & & \\
Kas & 25.045 .000 & 42.210 .000 & 28.645 .000 \\
Bank & 42.370 .000 & 62.100 .000 & 31.765 .250 \\
Piutang Usaha & 15.000 .000 & 20.000 .000 & 12.375 .000 \\
Piutang Lainnya & 5.750 .000 & 4.725 .000 & 2.895 .250 \\
Persediaan Bahan Baku & 28.000 .000 & 35.631 .250 & 24.000 .000 \\
Persediaan Barang Jadi & 39.700 .000 & 46.275 .000 & 25.772 .750 \\
\hline Jumlah Aktiva Lancar & $\mathbf{1 5 5 . 8 6 5 . 0 0 0}$ & $\mathbf{2 1 0 . 9 4 1 . 2 5 0}$ & $\mathbf{1 2 5 . 4 5 4 . 0 0 0}$ \\
\hline HUTANG LANCAR & & & \\
Hutang Usaha & 43.601 .333 & 55.680 .250 & 47.214 .500 \\
Hutang Lainnya & 9.837 .431 & 12.639 .750 & 11.792 .500 \\
\hline Jumlah Hutang Lancar & $\mathbf{5 3 . 4 3 8 . 7 6 4}$ & $\mathbf{6 8 . 3 2 0 . 0 0 0}$ & $\mathbf{5 9 . 0 0 7 . 0 0 0}$ \\
\hline Modal Kerja Bersih & $\mathbf{1 0 2 . 4 2 6 . 2 3 6}$ & $\mathbf{1 4 2 . 6 2 1 . 2 5 0}$ & $\mathbf{6 6 . 4 4 7 . 0 0 0}$ \\
\hline Perkembangan (\%) & & $\mathbf{3 9 , 2 4}$ & $\mathbf{5 3 , 4 1})$ \\
\hline
\end{tabular}

Berdasarkan Tabel dapat diketahui perkembangan modal kerja Dodol Kentang Putri Pancuran Tujuh Lubuk Nagodang Kerinci dari tahun 2017-2019. Modal kerja bersih pada Dodol Kentang Putri Pancuran Tujuh Lubuk Nagodang Kerinci selama periode 2017-2019 adalah berfluktuasi, namun menunjukkan bahwa untuk periode tahun 20172019 modal kerja bersih selalu bernilai positif. Dapat dilihat bahwa pada tahun 2017 jumlah aktiva lancar adalah sebesar Rp. 155.865.000,-, sedangkan jumlah hutang lancar adalah sebesar Rp. 53.438.764,-, hal ini menunjukkan bahwa jumlah modal kerja bersih adalah sebesar Rp. 102.426.236,-. Pada tahun 2018 jumlah hutang lancar meningkat menjadi Rp. 210.941.250,-, diikuti dengan kenaikan jumlah hutang lancar adalah sebesar Rp. 68.320.000,-, hal ini menunjukkan bahwa jumlah modal kerja bersih juga mengalami kenaikan sebesar Rp. 142.621.250,-. Dan pada tahun 2019 jumlah aktiva lancar mengalami penurunan menjadi Rp. 125.454.000,-, diikuti dengan penurunan jumlah hutang lancar sebesar Rp. 59.007.000,-, hal ini menunjukkan bahwa jumlah modal kerja bersih juga mengalami penurunan sebesar Rp.66.447.000,- 


\section{Analisis Sumber dan Penggunaan Modal Kerja Dodol Kentang Putri Pancuran Tujuh Lubuk Nagodang Kerinci}

Analisis sumber dan penggunaan modal kerja dilakukan dengan maksud untuk mengetahui bagaimana kebutuhan modal kerja tersebut digunakan dan bagaimana kebutuhan modal kerja tersebut dibelanjai. Analisis sumber dan penggunaan modal kerja sangat penting bagi penganalisa intern dan ekstern, disamping masalah modal kerja erat hubungannya dengan operasional sehari-hari di Dodol Kentang Putri Pancuran Tujuh Lubuk Nagodang juga menunjukkan tingkat keamanan bagi para kreditur. Modal Kerja yang cukup sangat penting bagi Dodol Kentang Putri Pancuran Tujuh Lubuk Nagodang karena memungkinkan Dodol Kentang Putri Pancuran Tujuh Lubuk Nagodang untuk beroperasi seekonomis mungkin dan tidak mengalami kesulitan atau menghadapi bahayabahaya yang mungkin terjadi karena adanya krisis atau kekacauan keuangan. Dengan analisa ini juga akan memberikan informasi kebutuhan akan modal kerja dimasa yang akan datang.

Dengan analisis ini dapat diadakan penilaian terhadap fungsi keuangan secara umum, suatu analisis terhadap sumber dan penggunaan dana dimasa lalu menunjukkan seberapa besar pertumbuhan perusahaan yang dibelanjai dari dalam perusahaan dan seberapa besar pertumbuhan perusahaan yang dibelanjai dari dalam perusahaan dan seberapa besar pertumbuhan perusahaan yang dibelanjai dari luar perusahaan.

Untuk mengetahui sumber dan penggunaan modal kerja Dodol Kentang Putri Pancuran Tujuh Lubuk Nagodang Kerinci periode 2017-2019, langkah yang harus dilakukan adalah menyusun laporan perubahan modal kerja serta laporan sumber dan penggunaan modal kerja. Berikut disajikan Laporan Perubahan Modal Kerja Bersih, Laporan Perubahan Non Modal Kerja serta Laporan Sumber dan Penggunaan Modal Kerja Dodol Kentang Putri Pancuran Tujuh Lubuk Nagodang Kerinci periode 2017 -2019.

\section{Laporan Perubahan Modal Kerja}

Penyajian laporan tentang perubahan modal kerja memerlukan analisis tentang kenaikan atau penurunan dalam pos-pos yang tercermin dalam dua titik waktu. Dari laporan perubahan modal kerja ini dapat dikelompokkan ke dalam pos-pos yang dapat memperrbesar/memperkecil modal kerja. Hal tersebut akan mencerminkan adanya sumber dan penggunaan modal kerja. Berikut ini ditampilkan laporan perubahan modal kerja bersih antara dua titik waktu pada Dodol Kentang Putri Pancuran Tujuh Lubuk Nagodang Kerinci selama periode 2017 - 2019.

\section{a. Laporan Perubahan Modal Kerja periode 2017 -2018}

Perubahan modal kerja khususnya dalam modal kerja kualitatif dapat terjadi karena adanya kenaikan atau penurunan di dalam aktiva lancar maupun hutang lancarnya. Perubahan modal kerja Dodol Kentang Putri Pancuran Tujuh Lubuk Nagodang Kerinci selama 2017 - 2018 dapat dilihat pada tabel berikut ini :

Tabel 2. Laporan Perubahan Modal Kerja Dodol Kentang Putri Pancuran Tujuh Lubuk Nagodang Periode 31 Desember 2017-31 Desember 2018

( Ribuan Rupiah )

\begin{tabular}{|l|r|r|r|r|}
\hline \multirow{2}{*}{ Keterangan } & \multirow{2}{*}{$\mathbf{2 0 1 7}$} & \multirow{2}{*}{$\mathbf{2 0 1 8}$} & \multicolumn{2}{c|}{ Perubahan Modal Kerja } \\
\cline { 4 - 6 } & & & bertambah & berkurang \\
\hline AKTIVA LANCAR & & & & \\
Kas & 25.045 .000 & 42.210 .000 & 17.165 .000 & \\
Bank & 42.370 .000 & 62.100 .000 & 19.730 .000 & \\
Piutang usaha & 15.000 .000 & 20.000 .000 & 5.000 .000 & \\
Piutang lainnya & 5.750 .000 & 4.725 .000 & & 1.025 .000 \\
\hline
\end{tabular}




\begin{tabular}{|c|c|c|c|c|}
\hline $\begin{array}{l}\text { Persediaan bahan baku } \\
\text { Persediaan barang jadi }\end{array}$ & $\begin{array}{l}28.000 .000 \\
39.700 .000\end{array}$ & $\begin{array}{l}35.631 .250 \\
46.275 .000\end{array}$ & $\begin{array}{l}7.631 .250 \\
6.575 .000\end{array}$ & \\
\hline Jumlah Aktiva Lancar & 155.865 .000 & 210.941 .250 & & \\
\hline $\begin{array}{l}\text { HUTANG LANCAR } \\
\text { Hutang Usaha } \\
\text { Hutang Lainnya }\end{array}$ & $\begin{array}{r}43.601 .333 \\
9.837 .431\end{array}$ & $\begin{array}{l}55.680 .250 \\
12.639 .750\end{array}$ & $\begin{array}{r}12.078 .917 \\
2.802 .319\end{array}$ & \\
\hline Jumlah Hutang Lancar & 53.438 .764 & 68.320.000 & & \\
\hline MODAL KERJA & 102.426.236 & 142.621.250 & & \\
\hline \multirow{3}{*}{\multicolumn{3}{|c|}{$\begin{array}{l}\text { Kenaikan Modal Kerja } \\
\text { Jumlah }\end{array}$}} & 70.982 .486 & 1.025 .000 \\
\hline & & & & 69.957.486 \\
\hline & & & 70.982 .486 & 70.982 .486 \\
\hline
\end{tabular}

Berdasarkan tabel dapat diketahui bahwa perubahan-perubahan dalam komponen modal kerja pada Dodol Kentang Putri Pancuran Tujuh Lubuk Nagodang Kerinci baik yang berasal dari komponen aktiva lancar maupun dari komponen hutang lancar selama periode 2017 - 2018 terjadi perubahan bertambahnya modal kerja sebesar Rp. 70.982.486,- dan berkurangnya modal kerja sebesar Rp. 1.025.000,-, sehingga terjadi kenaikkan modal kerja sebesar Rp. 69.957.486,--

Perubahan-perubahan dalam komponen modal kerja Dodol Kentang Putri Pancuran Tujuh Lubuk Nagodang Kerinci selama periode 2017 - 2018 ditunjukkan oleh :

1. Perubahan pada pos aktiva lancar

a. Kas

Perubahan kas terjadi karena adanya kenaikan atau penurunan nilai aktiva dan pasiva. Perubahan-perubahan dalam nilai aktiva ini mempunyai efek memperbesar kas yang disebut sebagai sumber penerimaan kas, sebaliknya penurunan dalam nilai aktiva dan pasiva yang mempunyai efek memperkecil kas disebut sebagai penggunaan kas. Kenaikan kas dapat terjadi karena sumber penerimaan kas lebih besar dari pada penggunaan kas itu sendiri.

Kas pada tahun 2017 adalah sebesar Rp. 25.045.000,- mengalami peningkatan pada tahun 2018 menjadi sebesar Rp. 42.210.000,- atau naik sebesar Rp. 17.165.000,-. Hal ini terjadi karena adanya sumber penerimaan kas yang lebih besar dari pada penggunaan kas. Seperti misalnya adanya peningkatan keuntungan, penjualan aktiva, dan adanya pembayaran piutang.

b. Bank

Bank pada tahun 2017 adalah sebesar Rp. 42.370.000,- mengalami peningkatan pada tahun 2018 menjadi sebesar Rp. 62.100.000,- atau naik sebesar Rp. 19.730.000,- . Hal ini dkarenakan adanya penerimaan bunga tabungan.

c. Piutang Usaha

Piutang usaha pada tahun 2017 adalah sebesar Rp. 15.000.000,- mengalami peningkatan pada tahun 2018 menjadi sebesar Rp.20.000.000,- atau naik sebesar Rp. 5.000.000,-. Hal ini dikarenakan meningkatnya penjualan kredit.

d. Piutang Lainnya

Piutang lainnya pada tahun 2017 adalah sebesar Rp. 5.757.000,- mengalami penurunan pada tahun 2018 menjadi sebesar Rp.4.725.000,- atau turun sebesar Rp. 1.025.000,-.

e. Persediaan Bahan Baku

Persediaan bahan baku pada tahun 2017 adalah sebesar Rp.28.000.000,- mengalami peningkatan pada tahun 2018 menjadi sebesar Rp. 35.632.250,- atau naik sebesar Rp. 7.631.250,-. Hal ini dikarenakan adanya pembelian bahan baku.

f. Persediaan Barang Jadi 
Persediaan Barng Jadi pada tahun 2017 adalah sebesar Rp.39.700.000,- mengalami peningkatan pada tahun 2018 menjadi sebesar Rp.46.275.000,- atau naik sebesar Rp. 6.575.000,-. Hal ini dikarenakan adanya peningkatan penimpanan barang digudang.

2. Perubahan pada pos hutang lancar

a. Hutang usaha

Hutang usaha pada tahun 2017 adalah sebesar Rp. 43.601.333,- mengalami peningkatan pada tahun 2018 menjadi sebesar Rp.55.680.250,- atau naik sebesar Rp. 12.078.917,-Hal ini dikarenakan adanaya peningkatan pembelian kredit perusahaan.

b. Hutang lainnya

Hutang lainnya pada tahun 2017 adalah sebesar Rp. 9.837.431,- mengalami peningkatan pada tahun 2018 menjadi sebesar Rp.12.639.750,- ataun naik sebesar Rp. 2.802.319,-. Hal ini dikarenakan adanya tambahan pinjaman jangka pendek.

\section{b. Laporan Perubahan Modal Kerja Periode 2018 - 2019}

Selanjutnya untuk mengetahui perubahan modal kerja pada Dodol Kentang Putri Pancuran Tujuh Lubuk Nagodang Kerinci periode 2017 - 2019, dapat dilihat pada tabel berikut ini :

\section{Tabel 3. Laporan Perubahan Modal Kerja CV. Tulimario Tanngkit Baru Jambi Periode 31 Desember 2017 - 31 Desember 2019 ( Ribuan Rupiah )}

\begin{tabular}{|c|c|c|c|c|}
\hline \multirow{2}{*}{ Keterangan } & \multirow{2}{*}{2018} & \multirow{2}{*}{2019} & \multicolumn{2}{|c|}{ Perubahan Modal Kerja } \\
\hline & & & bertambah & berkurang \\
\hline AKTIVA LANCAR & & & & \\
\hline Kas & 42.210 .000 & 28.645 .000 & & 13.565 .000 \\
\hline Bank & 62.100 .000 & 31.765 .250 & & 30.334 .750 \\
\hline Piutang usaha & 20.000 .000 & 12.375 .000 & & 7.625 .000 \\
\hline Piutang lainnya & 4.725 .000 & 2.895 .250 & & 1.829 .750 \\
\hline Persediaan bahan baku & 35.631 .250 & 24.000 .750 & & 11.630 .500 \\
\hline Persediaan barang jadi & 46.275 .000 & 25.772 .750 & & 20.502 .250 \\
\hline Jumlah Aktiva Lancar & 210.941 .250 & 125.454 .000 & & \\
\hline $\begin{array}{l}\text { HUTANG LANCAR } \\
\text { Hutang Usaha } \\
\text { Hutang Lainnya }\end{array}$ & $\begin{array}{l}55.680 .250 \\
12.639 .750\end{array}$ & $\begin{array}{l}47.214 .500 \\
11.792 .500\end{array}$ & & $\begin{array}{r}8.465 .750 \\
847.250\end{array}$ \\
\hline Jumlah Hutang Lancar & 68.320.000 & 59.007 .000 & & \\
\hline MODAL KERJA & 142.621 .250 & 66.447 .000 & & \\
\hline & - & 94.800 .250 \\
\hline \multicolumn{3}{|l|}{ Penurunan Modal Kerja } & 94.800 .250 & - \\
\hline \multicolumn{3}{|l|}{ Jumlah } & 94.800 .250 & 94.800 .250 \\
\hline
\end{tabular}

Berdasarkan tabel 3 dapat diketahui bahwa perubahan-perubahan dalam komponen modal kerja pada Dodol Kentang Putri Pancuran Tujuh Lubuk Nagodang Kerinci baik yang berasal dari komponen aktiva lancar maupun dari komponen hutang lancar selama periode 2017 - 2018 terjadi perubahan berkurangnya modal kerja sebesar Rp. 94.800.250,-

1. Perubahan pada Pos Aktiva Lancar

a. Kas 
Kas pada tahun 2018 adalah sebesar Rp. 42.210.000,-- mengalami penurunan pada tahun 2019 menjadi sebesar Rp. 28.645.000,- atau turun sebesar Rp. 13.565.000,-- Hal ini dikarenakan adanya pembayaran / pelunasan hutang, pembelian aktiva tetap, pembelian bahan baku.

\section{b. Bank}

Bank pada tahun 2018 adalah sebesar Rp. 62.100.000,- mengalami penurunan pada tahun 2019 menjadi sebesar Rp. 31.765.250,- atau turun sebesar Rp. 30.334.750,-. Hal ini dikarenakan penarikan tunai oleh pemilik.

c. Piutang Usaha

Piutang usaha pada tahun 2018 adalah sebesar Rp. 20.000.000,- mengalami penurunan pada tahun 2019 menjadi sebesar Rp.12.375.000,- atau turun sebesar Rp. 7.625.000,-. Hal ini dikarenakan berkurangnya penjualan kredit.

d. Piutang Lainnya

Piutang lainnya pada tahun 2018 adalah sebesar Rp. 4.725.000,- mengalami penurunan pada tahun 2019 menjadi sebesar Rp. 2.895.250,- atau turun sebesar Rp. 1.829.750,-. Hal ini dikarenakan adanya pembayaran hutang dari karyawan.

e. Persediaan Bahan Baku

Persediaan bahan baku pada tahun 2018 adalah sebesar Rp. 35.631.250,- mengalami penurunan pada tahun 2019 menjadi sebesar Rp.24.000.750,- atau turun sebesar Rp. 11.630.500,-. Hal ini dikarenakan tidak adanya pembelian pabahan baku.

f. Persediaan Barang Jadi

Persediaan barang jadi pada tahun 2018 adalah sebesar Rp. 46.275.000,- mengalami penurunan pada tahun 2019 menjadi sebesar Rp.25.772.750,- atau turun sebesar Rp. 20.502.250,-. Hal ini dikarenakan penurunan jumlah produksi.

2. Perubahan pada Pos Hutang Lancar

a. Hutang Usaha

Hutang usaha pada tahun 2018 adalah sebesar Rp. 55.680.250,- mengalami penurunan pada tahun 2019 menjadi sebesar Rp.47.214.500,- atau turun sebesar Rp. 8.465.750,-. Hal ini dikarenakan pelunasan hutang dari pemililk.

b. Hutang Lainnya

Hutang lainnya pada tahun 2018 adalah sebesar Rp. 12.639.750,- mengalami penurunan pada tahun 2019 menjadi sebesar Rp.11.792.500,- atau turun sebesar Rp. 847.250,-. Hal ini dikarenakan pelunasan hutang jangka panjang.

\section{Laporan Perubahan Sumber dan Penggunaan Modal Kerja}

Informasi tentang sumber dan penggunaan modal kerja sangat penting tidak hanya bagi manajemen tetapi juga sangat berguna bagi para kreditur atau bankers jangka pendek lainnya karena dengan mengetahui sumber dan penggunaan modal kerja perusahaan yang bersangkutan akan dapat digunakan sebagai dasar penilaian kebijaksanaan manajemen dalam mengelola modal kerjanya dan dapat digunakan sebagai dasar pengambilan keputusan oleh kreditur atau bankers tersebut (S. Munawir, 2007).

Setelah menyusun laporan perubahan modal kerja bersih, langkah selanjutnya adalah menyusun laporan perubahan non modal kerja tersebut, maka dapat diketahui unsur-unsur yang menjadi sumber modal kerja dan unsur-unsur yang merupakan penggunaan modal kerja yang kemudian disusun menjadi laporan sumber dan penggunaan modal kerja. Berikut ini disajikan laporan perubahan non modal kerja Dodol Kentang Putri Pancuran Tujuh Lubuk Nagodang Kerinci periode 2017-2019.

a. Laporan Sumber dan Penggunaan Non Modal Kerja Periode 2017 - 2018 
Laporan perubahan non modal kerja disusun untuk mengetahui unsur-unsur yang menjadi sumber modal kerja dan unsur yang merupakan penggunaan modal kerja. Berikut ini adalah laporan perubahan non modal kerja selama periode 2017 - 2018.

Tabel 4. Laporan Perubahan Non Modal Kerja CV. Tulimario Tanngkit Baru Jambi Periode 31 Desember 2017 - 31 Desember 2018 ( Ribuan Rupiah )

\begin{tabular}{|c|c|c|c|c|}
\hline \multirow[b]{2}{*}{ Keterangan } & \multirow[b]{2}{*}{2017} & \multirow[b]{2}{*}{2018} & \multicolumn{2}{|c|}{ Perubahan } \\
\hline & & & Sumber & $\begin{array}{l}\text { Pengguna } \\
\text { An }\end{array}$ \\
\hline $\begin{array}{l}\text { AKTIVA TETAP } \\
\text { Tanah } \\
\text { Bangunan } \\
\text { Mesin dan Peralatan } \\
\text { Akm. Penyusutan } \\
\text { HUTANG JK.PNJG } \\
\text { MODAL SENDIRI } \\
\text { Kenaikan Laba }\end{array}$ & $\begin{array}{c}100.000 .000 \\
50.000 .000 \\
75.000 .000 \\
(26.117 .132) \\
55.273 .129 \\
246.035 .975 \\
33.417 .886\end{array}$ & $\begin{array}{c}125.000 .000 \\
53.500 .000 \\
78.925 .000 \\
(32.843 .312) \\
83.181 .000 \\
284.021 .938 \\
44.870 .816\end{array}$ & $\begin{array}{r}6.726 .180 \\
27.907 .870 \\
37.985 .963 \\
11.452 .930\end{array}$ & $\begin{array}{r}25.000 .000 \\
3.500 .000 \\
3.925 .000\end{array}$ \\
\hline \multicolumn{3}{|l|}{$\begin{array}{l}\text { Jumlah } \\
\text { Kenaikan Modal } \\
\text { Kerja }\end{array}$} & 84.072 .943 & \begin{tabular}{|l|}
32.425 .000 \\
51.647 .943 \\
\end{tabular} \\
\hline
\end{tabular}

Berdasarkan laporan perubahan non modal kerja dan laporan perubahan modal kerja, dapat disusun laporan sumber dan penggunaan modal kerja Dodol Kentang Putri Pancuran Tujuh Lubuk Nagodang Kerinci . Berikut disajikan laporan sumber dan penggunaan modal kerja CV. Tulimario Taangkit Baru Jambi selama periode 2017-2018.

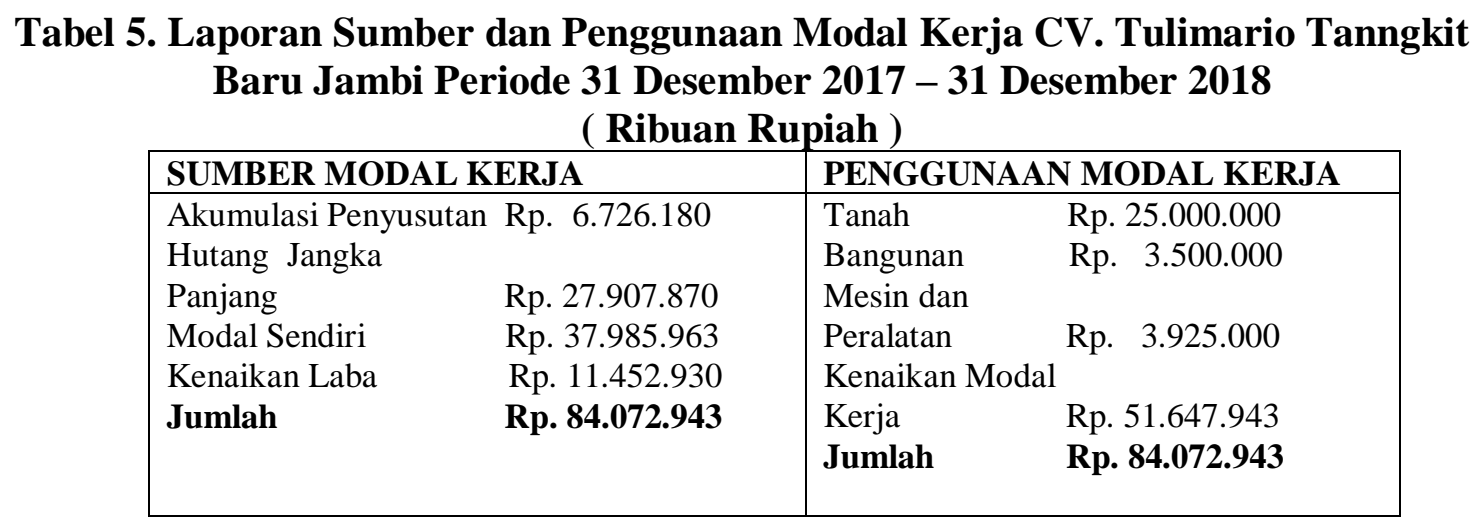

Berdasarkan tabel 4 dan tabel 5 diatas dapat diketahui bahwa selama periode 2017 - 2018 sumber dana yang dihimpun oleh Dodol Kentang Putri Pancuran Tujuh Lubuk Nagodang Kerinci untuk membiayai kebutuhan jangka panjang adalah sebesar RP. 84.072.943,-Sumber dana ini secara keseluruhan bersumber dari sumber jangka panjang antara lain diperoleh dari :

-Akumulasi penyusutan sebesar Rp. 6.726.180,-.

-Hutang jangka panjang sebesar Rp. 27.907.87.,--

- Modal sendiri sebesar Rp. 37.985.963,-.

-Kenaikan laba Rp. 11.452.930,-.

Sedangkan penggunaan modal kerja terbesar digunakan untuk pembelian tanah sebesar Rp. 25.000.000,-, modal kerja juga digunakan untuk perbaikan bangunan yaitu sebesar Rp. 3.500.000,- dan pemeliharaan mesin dan peralatan yaitu sebesar Rp. 3.925.536,-. 


\section{b. Laporan Sumber dan Penggunaan Non Modal Kerja Periode 2018 - 2019}

Selanjutnya untuk mengetahui laporan sumber dan penggunaan modal kerja selama periode 2018 - 2019 maka terlebih dahulu disusun laporan perubahan non modal kerja. Laporan perubahan non modal kerja Dodol Kentang Putri Pancuran Tujuh Lubuk Nagodang Kerinci selama periode 2018 - 2019 dapat dilihat pada tabel 6 berikut ini :

\section{Tabel 6. Laporan Perubahan Non Modal Kerja CV. Tulimario Tanngkit Baru Jambi Periode 31 Desember 2018 - 31 Desember 2019 \\ ( Ribuan Rupiah )}

\begin{tabular}{|c|c|c|c|c|}
\hline \multirow{2}{*}{ Keterangan } & \multirow{2}{*}{2018} & \multirow{2}{*}{2019} & \multicolumn{2}{|c|}{ Modal Kerja } \\
\hline & & & Sumber & Penggunaan \\
\hline AKTIVA TETAP & & & & \\
\hline Tanah & 125.000 .000 & 150.000 .000 & & 25.000 .000 \\
\hline Bangunan & 53.500 .000 & 58.825 .000 & & 5.325 .000 \\
\hline Mesin dan Peralatan & 78.925 .000 & 72.376 .500 & 6.548 .500 & \\
\hline Akm. Penyusutan & $(32.843 .312)$ & $(23.169 .500)$ & 9.673 .812 & \\
\hline HUTANG JK.PNJG & 83.181 .000 & 48.036 .500 & & 35.144 .500 \\
\hline MODAL SENDIRI & 284.021 .938 & 276.442 .500 & & 7.579 .438 \\
\hline Penurunan Laba & 44.870 .816 & 33.709 .853 & & 11.160 .963 \\
\hline \multirow{2}{*}{\multicolumn{3}{|c|}{$\begin{array}{l}\text { Jumlah } \\
\text { Kekurangan modal } \\
\text { Kerja }\end{array}$}} & 16.222.312 & 84.209.901 \\
\hline & & & 67.987.589 & \\
\hline
\end{tabular}

Berdasarkan laporan perubahan non modal kerja dan laporan perubahan modal kerja, dapat disusun laporan sumber dan penggunaan modal kerja Dodol Kentang Putri Pancuran Tujuh Lubuk Nagodang Kerinci selama periode 2018-2019 sebagai berikut:

\section{Tabel 7. Laporan Sumber dan Penggunaan Modal Kerja CV. Tulimario Tanngkit Baru Jambi Periode 31 Desember 2018 - 31 Desember 2019 ( Ribuan Rupiah )

\begin{tabular}{|lll|ll|}
\hline \multicolumn{2}{|l|}{ SUMBER MODAL KERJA } & \multicolumn{3}{l|}{ PENGGUNAAN MODAL KERJA } \\
\hline Mesin dan Peralatan & Rp. 6.548 .500 & Tanah & Rp. 25.000.000 \\
AkumulasiPenyusutan & Rp. $\quad 9.673 .812$ & Bangunan & Rp. 5.325 .000 \\
Kekurangan Modal & & Hutang Jangka & \\
Kerja & Rp. 67.267.941 & Panjang & Rp. 35.144 .500 \\
& & Modal Sendiri & Rp. 7.579 .438 \\
Jumlah & & Penurunan Laba Rp. 11.160 .963 \\
& Rp. 84.209.901 & Jumlah & Rp. 83.209.941
\end{tabular}

Berdasarkan tabel 6 dan 7 di atas dapat diketahui bahwa pada tahun 2018 - 2019 sumber dana yang dihimpun oleh Dodol Kentang Putri Pancuran Tujuh Lubuk Nagodang Kerinci untuk membiayai kebutuhan jangka panjang adalah sebesar Rp.84.209.901,--, berasal dari sumber jangka pendek sebesar Rp.67.987.589,-, dan sumber jangka panjang sebesar Rp.16.222.312,-. Sumber jangka pendek ditunjukkan adanya penurunan modal kerja yaitu sebesar Rp. 67.987.589,-. Sedangkan sumber jangka panjang dipeoleh dari mesin dan peralatan sebesar Rp. 6.548.500,-, akumulasi penyusutan sebesar Rp. 9.673.812,--

Sedangkan penggunaan dana terbesar diserap untuk membayar hutang jangka panjang sebesar Rp. 35.144.500,-, modal kerja juga digunakan untuk tanah sebesar Rp. 25.000.000,-, bangunan sebesar Rp.5.325.000,-, modal sendiri sebesar Rp. 7.579.438,-, dan penurunan laba sebesar Rp. 11.160.963,--

Jadi, pada periode 2018 - 2019 terjadi penurunan modal kerja sebesar Rp.11.160.963,-. Hal ini berarti adanya sumber modal kerja jangka pendek yang digunakan untuk membiayai penggunaan modal kerja jangka panjang atau dengan kata lain untuk 
menutupi kekurangan sumber mudal kerja jangka panjang diperoleh dari sumber jangka pendek. Kebijaksanaan yang diambil Dodol Kentang Putri Pancuran Tujuh adalah kurang tepat karena tidak sesuai dengan prinsip pembiayaan yaitu sumber modal jangka pendek belum boleh digunakan untuk membiayai kebutuhan jangka panjang.

\section{KESIMPULAN}

Berdasarakan hasil analisis sumber dan penggunaan modal kerja Dodol Kentang Putri Pancuran Tujuh Lubuk Nagodang Kerinci Periode 2017 - 2010, maka dapat ditarik kesimpulan sebagai berikut :

1. Berdasarkan perkembangan modal kerja bersih Dodol Kentang Putri Pancuran Tujuh Lubuk Nagodang Kerinci selama periode 2017 - 2019 adalah berfluktuasi. Pada tahun 2017 jumlah modal kerja bersih adalah Rp. 102.426.236,- mengalami peningkatan pada tahun 2018 sebesar Rp. 142.212.250,- atau naik sebesar $39,24 \%$, dan pada tahun 2019 jumlah modal kerja bersih mengalami penurunan sebesar Rp. 66.447.000,- atau turun sebesar 53,41\%.

2. Berdasarkan laporan perubahan modal kerja Dodol Kentang Putri Pancuran Tujuh Lubuk Nagodang Kerinci selama periode 2006 - 2008 adanya penambahan dan pengurangan baik pada komponen aktiva lancar ataupun pada komponen hutang lancar, maka dapat diketahui selama periode tahun 2017 - 2018 terjadi penambahan modal kerja sebesar Rp. 69.957.000,- dan selama periode tahun 2018 - 2019 terjadi penurunan modal kerja sebesar Rp. 94.800.250,-Berdasarkan analisis sumber dan penggunaan modal kerja dapat diketahui sumber dan penggunaan modal kerja pada Dodol Kentang Putri Pancuran Tujuh Lubuk Nagodang Kerinci selama periode 2017 - 2019. Diketahui pada tahun 2018 terdapat kelebihan modal kerja yang digunakan untuk membiayai kebutuhan jangka pendek (aktiva lancar). Hal ini berarti kebijaksanaan yang diambil oleh Dodol Kentang Putri Pancuran Tujuh Lubuk Nagodang Kerinci pada tahun 2018 sudah tepat, karena telah memenuhi persyaratan prinsip pembiayaan. Namun pada tahun 2019 terdapat kekurangan modal kerja, sehingga untuk menutupi kekurangan modal kerja maka Dodol Kentang Putri Pancuran Tujuh Lubuk Nagodang Kerinci menggunakan dana jangka pendek. Kebijaksanaan yang diambil oleh Dodol Kentang Putri Pancuran Tujuh Lubuk Nagodang Kerinci pada tahun 2019 menggunakan kebijaksanaan agresif karena Dodol Kentang Putri Pancuran Tujuh Lubuk Nagodang Kerinci menggunakan sumber modal jangka pendek untuk membiayai kebutuhan jangka panjang.

\section{DAFTAR PUSTAKA}

Adelina, A., \& Darman, D. (2021). Analisis Sumber Dan Penggunaan Dana Pt.Bumi Sarana Utama Cabang Palu. Jurnal Ilmu Manajemen Universitas Tadulako (JIMUT), 7(3). Https://Doi.Org/10.22487/Jimut.V7i3.244

Agus Sartono. 2001. Manajemen Keuangan Teori Dan Aplikasinya. BPFE, Yogyakarta. Agus Sabardi. 1994. Manajemen Keuangan. UPPAMP YKPN. Yogyakarta.

Bambang Riyanto. 2001. Dasar-dasar Pembelanjaan Perusahaan. BPFE. Yogyakarta.

Djatmiko, Hayati Yayat. 2005. Perilaku Organisasi. Alfabeta. Bandung

Handoko, T. Hani. 1995. Manajemen. BPFE. Yogyakarta. Alfabeta. Bandung.

Jumingan. 2006. Analisis Laporan Keuangan. PT. Bumi Aksara. Surakarta.

Kasmir. 2008. Analisis laporan keuangan. Rajawali Pers, Jakarta

Kuncoro Mudrajad. 2003. Metode Riset Untuk Bisnis \& Ekonomi. Erlangga. Jakarta. 
Lukman Syamsudin. 2001. Manajemen Keuangan Perusahaan ( Konsep Apilkasi Dalam Perencanaan, Pengawasan, dan Pengambilan Keputusan ). Rajawali Pers. Jakarta.

Martono SU. 2005. Manajemen keuangan, Ekonisia Yogyakarta

Ridwan S. Sundjaya dan Inge Berlian.2001. Manajemen Keuangan Satu. Prenhallindo. Jakarta.

Suad Husnan dan Enny Pudjiastuti, 2004. Dasar-dasar Manajemen Keuangan. UPPAMP YKPN, Yogyakarta.

Sutrisno. 2007, Manjemen Keuangan Teori, Konsep dan Aplikasinya. Edisi Kelima, Ekonisia. Yogyakarta.

Sugiyono. 2002. Metode Penelitian Bisnis. Alfabeta. Bandung

S. Munawir. 2007. Analisis laporan Keuangan. Liberty. Yogyakarta.

Aminah, "Analisis Sumber dan Penggunaan Modal Kerja pada Koperasi Pegawai Negeri Sipil ( KPN ) RSUD Raden Mattaher Jambi Periode 2002 - 2006”.

Meriyanti, "Analisis Sumber dan Penggunaan Modal Kerja pada PDAM Tirta Mayang

Kota Jambi Periode 2002 - 2005".

Yanti, K. N., Sujana, I. N., \& Zukhri, A. (2019). Analisis Sumber Dan Penggunaan Modal Kerja Pada Koperasi Simpan Pinjam Artha Guna Bhakti Tahun 2017 Singaraja. Jurnal Pendidikan Ekonomi Undiksha, 9(2). https://doi.org/10.23887/jjpe.v9i2.20153 